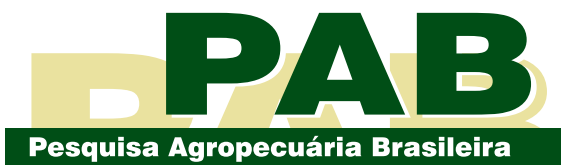

ISSN 1678-3921

Journal homepage: www.embrapa.br/pab

For manuscript submission and journal contents, access: www.scielo.br/pab

\section{Performance of 'Vitória' pineapple in response to different types of shoots and ages of floral induction}

\begin{abstract}
The objective of this work was to evaluate the effect of shoot types and plant ages for floral induction on the performance of 'Vitória' pineapple (Ananas comosus). The experiment was carried out from April 2015 to December 2016, using shoots of two different classifications (slips of 100 to $200 \mathrm{~g}$ and suckers of 201 to $300 \mathrm{~g}$ ). Artificial floral induction was performed at the eighth, tenth, and twelfth months after planting, and natural induction was also evaluated. Evaluations for vegetative development, phenology, and productivity were performed. A significant interaction was observed between the studied factors for width and area of the "D" leaf. Shoot type did not influence productivity. Natural flowering extended the crop cycle by 617 days. The induction performed at the eighth month anticipated harvest by up to 167 days. Earlier inductions reduced productivity by $58.15 \%$ due to the reduction of fruit mass. Naturally induced plants produced larger fruit ranging from 1.0 to $1.2 \mathrm{~kg}$. Inductions from the eighth to the tenth month promote harvesting in more favorable seasons.
\end{abstract}

Index terms: Ananas comosus, flowering, production scheduling.

\section{Desempenho do abacaxizeiro 'Vitória' em resposta a diferentes tipos de mudas e idades de indução floral}

Resumo - O objetivo deste trabalho foi avaliar o efeito de tipos de mudas e idades da planta para a indução floral no desempenho do abacaxizeiro 'Vitória' (Ananas comosus). O experimento foi realizado de abril de 2015 a dezembro de 2016, com mudas de duas classificações diferentes (filhotes com 100 a 200 g e rebentão com 201 a 300 g). A indução floral artificial foi feita no oitavo, no décimo e no décimo-segundo mês após o plantio, e a indução natural também foi avaliada. Realizaram-se avaliações quanto ao desenvolvimento vegetativo, à fenologia e à produtividade. Observou-se interação significativa entre os fatores estudados quanto à largura e à área da folha "D". O tipo de muda não influenciou a produtividade. O florescimento natural estendeu o ciclo da cultura em 617 dias. A indução realizada no oitavo mês antecipou a colheita em até 167 dias. Induções mais precoces reduziram a produtividade em $58,15 \%$, em razão da redução da massa dos frutos. Plantas induzidas naturalmente produziram frutos maiores, que variaram de 1,0 a 1,2 $\mathrm{kg}$. As induções do oitavo ao décimo mês possibilitam colheitas em épocas mais favoráveis.

Termos para indexação: Ananas comosus, florescimento, escalonamento da produção. 


\section{Introduction}

Brazil is the third largest pineapple producer worldwide, with 2,253,897 tonnes of fruit in 2017 (FAO, 2019). The fluctuation of fruit supply throughout the year is one of the main bottlenecks in the pineapple production chain (Sahoo et al., 2015). In the state of Espírito Santo, the highest prices paid to pineapple farmers occur in April, May, and July because of the supply reduction (Ceasa-ES, 2017). In order to be able to shift harvest seasons to more economically favorable periods of the year, it is necessary to define management strategies for the production scheduling.

Artificial flowering induction is among of some recommended strategies for production scheduling (Sahoo et al., 2015). The lower is the vigor of the plants at the time of floral induction, the lower will be the quality of fruit. In addition, the age of floral induction varies according to genotype and to the cultivation environment (Barker et al., 2018). For this reason, the ideal time to perform the floral induction should be identified to plan the control of the desirable harvesting season of fruit with market standard.

Planting time is the key for natural floral induction (Kist et al., 2011), as it influences the plant vegetative development (Ganem, 2015). Because the natural floral induction in pineapple occurs as a result of short days and low temperatures (Maruthasalam et al., 2010), management strategies should be created in the different producing regions for the different genotypes used.

The type and size of shoots used also influence the production cycle of pineapple (Fassinou Hotegni et al., 2015), therefore production scheduling is possible for planting shoots of different sizes (Reinhardt et al., 2018). In general, "slip" type shoots show a lower vigor than the suckers; thus, plants obtained from the suckers reach the appropriate size to induce flowering in a shorter time, which causes the reduction of the crop cycle (Reinhardt et al., 2018).

Studies on the management of pineapple flowering were performed mainly for the 'Smooth Cayenne', aiming to define methodologies for the scheduling of production in different regions in Brazil (Kist et al., 2011). However, there are few studies on the 'Vitória' pineapple, which is resistant to the fungus that causes fusariosis.

The objective of this work was to evaluate the effect of using different types of shoots and plant ages for floral induction on the performance of pineapple 'Vitória'.

\section{Materials and methods}

The experiment was carried out from April 2015 to December 2016, in the Sooretama Experimental Farm, of Incaper, located in the northern Espírito Santo state, Brazil, in the municipality of Sooretama (19'11'30"S, $40^{\circ} 05^{\prime} 46 \mathrm{~W}$, at $30 \mathrm{~m}$ altitude). The climate is classified as Aw - humid tropical, with dry winter and hot and humid summer, according to the Köppen-Geiger's classification (Alvares et al., 2013).

The experimental design was a randomized complete block in a split-plot arrangement $(2 \times 4)$, with eight treatments, and four replicates. Each plot consisted of 288 plants, 80 from which were useful plants composed of two types of shoots, classified as slips of 100-200 g, and suckers of 201-300 g. The splitplots consisted of 72 plants, and the 20 central useful plants were evaluated. Floral induction was performed at 8,10 , and 12 months after planting, besides the natural induction, according to the methodology of Kist et al. (2011). A total of 576 plants were used per block, totaling 2,304 plants, including those in the lateral borders.

Planting was done in double-row spacing $(0.9 \times 0.4 \times 0.30 \mathrm{~m})$, maintainedundera sprinkler-watering system of irrigation. Fertilization was performed according to the results of soil analysis, as indicated in the liming and fertilization recommendation manual for the state of Espírito Santo (Prezotti et al., 2007). All crop and phytosanitary treatments necessary for the adequate development of the crop were carried out. Artificial floral induction was performed using $100 \mathrm{mg} \mathrm{L}^{-1}$ ethephon (2-chloroethylphosphonic acid) based product by applying $30 \mathrm{~mL}$ per plant on the leaf rosette, according to Kist et al. (2011), between 8:00 and 9:00 $\mathrm{h}$.

At the time of floral induction, growth linear measurements of the " $D$ " leaf were evaluated for total length and width, in the lower-third using a millimeter ruler. Based on these measurements, the total leaf area was determined using the formula proposed by Francisco et al. (2014) for the 'Vitória' pineapple, as follows: $\mathrm{LA}=19.298(\mathrm{~L} \times \mathrm{W})-559.9$, in which $\mathrm{LA}$ is the total leaf area $\left(\mathrm{cm}^{2}\right), \mathrm{L}$ is the length, and $\mathrm{W}$ is the width of the " $\mathrm{D}$ " leaf. During this period, the

Pesq. agropec. bras., Brasília, v.55, e01598, 2020

DOI: 10.1590/S1678-3921.pab2020.v55.01598 
total number of plant leaves was also evaluated. For the study of the 'Vitória' pineapple growing cycle, the periods between floral induction and harvest onset were determined, as well as planting, start of harvest, and total days of harvest.

Daily data for temperature (in ${ }^{\circ} \mathrm{C}$, minimum, maximum, and average), rainfall $(\mathrm{mm})$ and relative humidity (\%) were obtained at the automatic weather station in the municipality of Linhares, in the state of Espírito Santo (Figure 1). The thermal requirements $\left({ }^{\circ} \mathrm{C}\right.$ days) were determined between planting and flowering induction (vegetative phase), in the flowering induction at the beginning of the harvest (reproductive phase), and between planting and the beginning of the harvest. For the characterization of thermal requirements, the thermal constants were calculated in degree-days (DD). When the minimum temperature $\left(T_{\min }\right)$ was higher than the base temperature $\left(\mathrm{T}_{\mathrm{b}}\right)$, the daily value $\left(\mathrm{DD}_{\mathrm{i}}\right)$ was given by the equation $\mathrm{DD}_{\mathrm{i}}=\mathrm{T}_{\text {Average }}-\mathrm{T}_{\text {bi }}$, in which $\mathrm{T}_{\text {Average }}$ is the average air temperature $\left({ }^{\circ} \mathrm{C}\right)$ of the day. When $T_{\text {Min }}$ was lower than $T_{b}, D_{i}$ was given by the equation $\mathrm{DD}_{\mathrm{i}}=\left[\left(\mathrm{T}_{\mathrm{Max}}-\mathrm{T}_{\mathrm{b}}\right)^{2}\right) /\left(2\left(\mathrm{~T}_{\mathrm{Max}}-\mathrm{T}_{\mathrm{Min}}\right)\right]$, proposed by Villa Nova et al. (1972), in which $\mathrm{T}_{\mathrm{Max}}$ is the maximum air temperature $\left({ }^{\circ} \mathrm{C}\right)$ of the day. The $\mathrm{T}_{\mathrm{b}}$ used was $15.8^{\circ} \mathrm{C}$ (Carvalho et al., 2005).

Fruit harvesting started in May 2016. Fruit were harvested at the maturity stage, corresponding to the spotted ones (up to $25 \%$ of its orange-yellow peel), according to the specific normative instruction for white flesh pineapple (Brasil, 2017). Yield was calculated $\left(\mathrm{Mg} \mathrm{ha}^{-1}\right)$, considering 20 fruit from each subplot, which were used to evaluate the average mass of crowned fruit, determined from weighing multiplied by planting density $\left(51,282\right.$ plants ha- $\left.{ }^{-1}\right)$.

Data were subjected to the analysis of variance, and means were compared by the Tukey test, at 5\% probability, using the Genes statistical software (Cruz, 2013).

\section{Results and Discussion}

A significant effect of induction time was observed on leaf growth and development (Table 1). For "D" leaf length of the, the highest mean was obtained with the

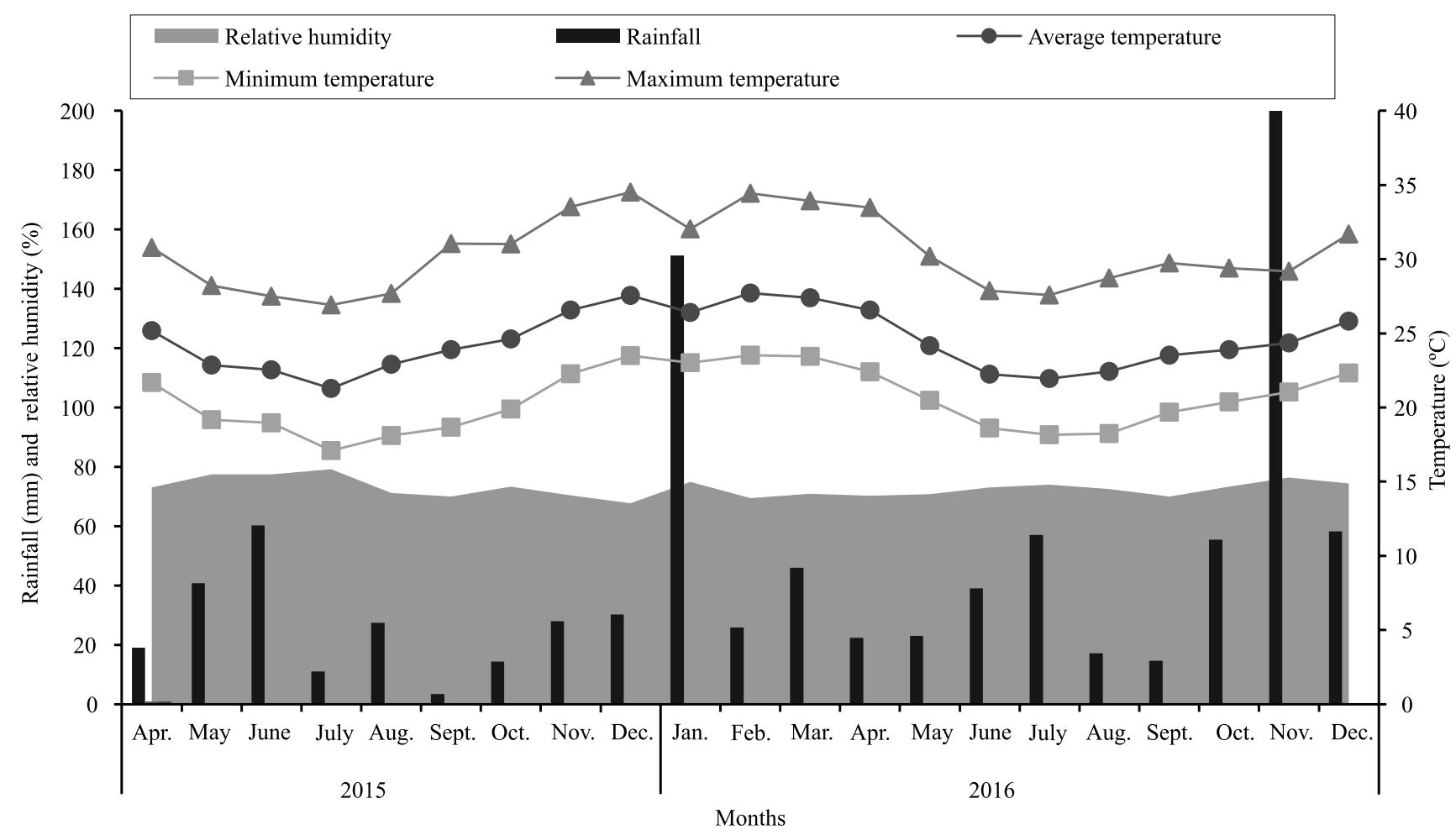

Figure 1. Total rainfall, relative humidity, and average, maximum, and minimum temperatures recorded at the weather station in the municipality of Linhares, in the state of Espírito Santo, from April/2015 to December/2016. 
induction at 12 months, and no influence of the shoot type was observed. For "D" leaf width, a significant interaction was observed between the studied factors. Naturally induced plants had the smallest "D" leaf width for both types of shoots. In artificially induced plants, an increase was found for the width, evidenced mainly in the inductions performed at 8 months, for both shoot types, and at 10 months for the slip shoot type. Plants induced at 12 months obtained intermediate values of width for the " $D$ " leaf.

The " $D$ " leaf has been considered the most important one in pineapple management, as it is able to reflect the nutritional status of the plant, and its development is used as an indicator of the ideal period for the artificial floral induction and for the prediction of fruit mass at harvest (Guarçoni \& Ventura, 2011). However, in the present study, the biometric characteristics of " $D$ " leaf were not considered to indicate plant vigor, since naturally induced plants had the lowest-width values of "D" leaf, and achieved the highest yield (Table 1) and fruit mass (Figure 2).

According to Küster et al. (2018), values for length and width of the " $D$ " leaf are strongly influenced by both genotype and environment, and they should not

Table 1. Vegetative development and yield of 'Vitória' pineapple (Ananas comosus) in response to the different types of shoots and ages of floral induction ${ }^{(1)}$.

\begin{tabular}{|c|c|c|c|c|c|}
\hline \multirow[t]{2}{*}{ Shoot } & \multicolumn{4}{|c|}{ Induction age } & \multirow[t]{2}{*}{ Mean } \\
\hline & 8 months & 10 months & 12 months & Natural & \\
\hline & \multicolumn{5}{|c|}{ "D" leaf length $(\mathrm{cm})$} \\
\hline Slip (100-200 g) & 55.46 & 63.46 & 65.52 & 60.98 & $61.36 \mathrm{~A}$ \\
\hline Sucker (201-300 g) & 58.79 & 56.17 & 67.29 & 59.85 & $60.53 \mathrm{~A}$ \\
\hline Mean & $57.12 b$ & $59.82 \mathrm{~b}$ & $66.41 \mathrm{a}$ & $60.42 b$ & \\
\hline CV $(\%)_{\text {Shoot type }}$ & & & 8.19 & & \\
\hline \multirow[t]{2}{*}{$\mathrm{CV}(\%)_{\text {Induction age }}$} & & & 6.44 & & \\
\hline & \multicolumn{5}{|c|}{ “D” leaf width (cm) } \\
\hline Slip (100-200 g) & $5.03 \mathrm{Aa}$ & $4.97 \mathrm{Aa}$ & $4.28 \mathrm{Ab}$ & $3.58 \mathrm{Ac}$ & \\
\hline Sucker (201-300 g) & $5.04 \mathrm{Aa}$ & $4.28 \mathrm{Bb}$ & $4.30 \mathrm{Ab}$ & $3.53 \mathrm{Ac}$ & \\
\hline $\mathrm{CV}(\%)_{\text {Shoot type }}$ & & & 1.73 & & \\
\hline \multirow[t]{2}{*}{$\mathrm{CV}(\%)_{\text {Induction age }}$} & & & 6.08 & & \\
\hline & \multicolumn{5}{|c|}{ Total leaf area $\left(\mathrm{cm}^{2}\right)$} \\
\hline Slip (100-200 g) & 4906.47Aa & 5591.76Aa & 4974.96Aa & $3686.19 \mathrm{Ab}$ & \\
\hline Sucker (201-300 g) & $5067.78 \mathrm{Aa}$ & $4241.75 \mathrm{Bab}$ & $5112.84 \mathrm{Aa}$ & $3547.76 \mathrm{Ab}$ & \\
\hline $\mathrm{CV}(\%)_{\text {Shoot type }}$ & & & 12.13 & & \\
\hline \multirow[t]{2}{*}{$\mathrm{CV}(\%)_{\text {Induction age }}$} & & & 11.8 & & \\
\hline & \multicolumn{5}{|c|}{ Number of leaves } \\
\hline Slip (100-200 g) & 26.76 & 31.54 & 37.73 & 47.22 & $35.81 \mathrm{~A}$ \\
\hline Sucker (201-300 g) & 27.68 & 28.31 & 39.07 & 45.71 & $35.19 \mathrm{~A}$ \\
\hline Mean & $27.22 \mathrm{c}$ & $29.92 \mathrm{c}$ & $38.40 \mathrm{~b}$ & $46.47 \mathrm{a}$ & \\
\hline $\mathrm{CV}(\%)_{\text {Shoot type }}$ & & & 13.57 & & \\
\hline \multirow[t]{2}{*}{$\mathrm{CV}(\%)_{\text {Induction age }}$} & & & 14.79 & & \\
\hline & \multicolumn{5}{|c|}{ Yield $\left(\mathrm{Mg} \mathrm{ha}^{-1}\right)$} \\
\hline Slip (100-200 g) & 25.41 & 34.69 & 38.99 & 55.60 & $38.67 \mathrm{~A}$ \\
\hline Sucker $(201-300 \mathrm{~g})$ & 21.58 & 25.31 & 28.62 & 56.67 & $33.05 \mathrm{~A}$ \\
\hline Mean & $23.49 \mathrm{c}$ & $30.00 \mathrm{bc}$ & $33.81 \mathrm{~b}$ & $56.13 \mathrm{a}$ & \\
\hline $\mathrm{CV}(\%)_{\text {Shoot type }}$ & & & 29.69 & & \\
\hline $\mathrm{CV}(\%)_{\text {Induction age }}$ & & & 18.79 & & \\
\hline
\end{tabular}

(1)Means followed by equal letters, uppercase in the columns and lowercase in the lines, do not differ by Tukey's test, at 5\% of probability. 
be used as quality indicators of pineapple fruit 'Vitória'. Pineapple leaf show a high plasticity, changing its morphological characteristics to optimize the use of environmental resources (Cheng et al., 2018).

For the total leaf area, the behavior was similar to that observed for the width of the " $D$ " leaf, with a significant interaction between the studied factors. The total leaf area was higher in artificially induced plants than in plants with natural flowering, except for the sucker type shoot induced at 10 months, which did not differ from other treatments.

The similarity of response of the total leaf area with that of the "D" width is probably due to the model proposed by Francisco et al. (2014), which uses the product of the linear dimensions of "D" leaf. Due to the existence of leaf plasticity in pineapple plants, and to the fact that the model had been obtained under controlled conditions, the results of the present study provide an indication that this model should be reviewed.

The environmental conditions over plant growth should also be considered (Figure 1). The induction at 8 months was performed in December, a period of high temperature and rainfall, which favors the leaf development of pineapple plants (Ebel et al., 2016). Therefore, the increase of the $D$ leaf width, in

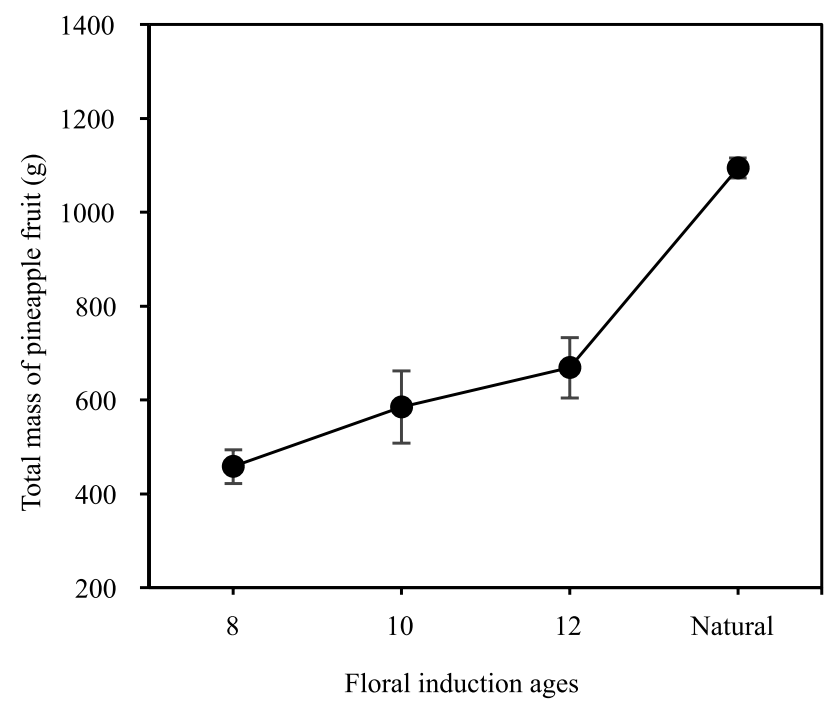

Figure 2. Total mass of 'Vitória' pineapple (Ananas comosus) fruit, planted in April 2015, originally from slip and sucker shoots artificially induced at 8, 10, 12 months after planting, and natural induction. Bars represent the standard error of the mean. plants induced at 8 and 10 months, may have caused a compensatory effect on the total leaf area due to the reduction of the number of leaves of induced plants (Table 1).

When sucker type shoots, which are heavier and with more stored nutrients (Fassinou Hotegni et al., 2015), were used, such effect was not observed in the induction at 10 months probably because, at this time, the plants had already had the ability to produce enough photoassimilates to support the reproductive period.

The largest number of leaves was found in natural floral induction (Table 1). In plants induced at 12 months, the number of leaves was higher than in plants induced at 8 and 10 months. The treatment of pineapple plants with Ethrel promotes an increase of the ethylene levels, and a reduction of gibberellin levels, as well as alterations in the expression of several genes, resulting in the induction of the apical meristem differentiation of the aerial part in flower buds (Espinosa et al., 2017). When the reproductive development begins, the apex stem meristem ceases to produce leaves and begins to produce flowers, which upon the inflorescence formation returns to the vegetative capacity, forming the crown (Reinhardt et al., 2018). In late inductions, plants will continue the vegetative development, producing new leaves over this period (Fassinou Hotegni et al., 2015).

The higher productivity in naturally induced plants and in the induction at 12 months, as well as the lowest productivity in plants induced at 8 and 10 months (Table 1), can be explained by the growth period before the floral induction (Table 2), which provided the vegetative development, evidenced by the number of leaves (Table 1). Therefore, a shorter period of vegetative development led to a lower accumulation of reserves and a lower ability to support fruiting (Figure 2). Plants accumulate reserve compounds over the vegetative period. Such compounds are redistributed in the post-induction period to fruit development and growth (Marques et al., 2013). Therefore, a later floral differentiation determines a longer period of vegetative growth, which leads to a greater accumulation of photoassimilates and promotes the formation of larger fruit (Kist et al., 2011).

The type of shoot used as propagative material influenced the leaf characteristics only in the induction performed at 10 months, with a greater width of the 
"D" leaf and total leaf area (Table 1). The type of shoot anticipated the harvest in one week, and the thermal sum from planting to the beginning of the upper harvest was $40^{\circ} \mathrm{C}$ day (Table 2). However, these differences did not influence the fruit yield (Table 1). It is likely that the initial variation of the weight of the propagating material used in the study was partially compensated during the crop development (Fassinou Hotegni et al.,
2015). Therefore, it is recommended that the farmers do not discriminate between these two shoot patterns at the establishment of 'Vitória' pineapple cultivation.

Considering the days from planting to harvest, and the duration of the harvest, a significant difference was observed between the induction ages, while for the time of floral induction to the beginning of the harvest, there was an effect of the induction age and of

Table 2. Planting to harvest onset period in days, floral induction to harvest onset, harvest duration, and thermal sum of 'Vitória' pineapple (Ananas comosus) plants in response to the different types of shoots and ages of floral induction ${ }^{(1)}$.

\begin{tabular}{|c|c|c|c|c|c|}
\hline \multirow{2}{*}{ Shoot } & \multicolumn{4}{|c|}{ Induction age } & \multirow{2}{*}{ Mean } \\
\hline & 8 months & 10 months & 12 months & Natural $^{(2)}$ & \\
\hline & Dec./2015 & Feb./2016 & May/2016 & & \\
\hline & \multicolumn{5}{|c|}{ Planting to harvest onset (days) } \\
\hline Slip (100-200 g) & 388.07 & 472.34 & 553.65 & 597.35 & $502.85 \mathrm{~A}$ \\
\hline Sucker (201-300 g) & 392.81 & 481.58 & 561.41 & 592.03 & $506.96 \mathrm{~A}$ \\
\hline Mean & $390.44 d$ & $476.96 \mathrm{c}$ & $557.53 b$ & $594.69 \mathrm{a}$ & \\
\hline $\mathrm{CV}(\%)_{\text {Shoot type }}$ & & & 0.80 & & \\
\hline \multirow[t]{2}{*}{$\mathrm{CV}(\%)_{\text {Induction age }}$} & & & 1.06 & & \\
\hline & \multicolumn{5}{|c|}{ Floral induction to harvest onset (days) } \\
\hline Slip (100-200 g) & 152.07 & 172.34 & 174.65 & - & $166.35 \mathrm{~B}$ \\
\hline Sucker (201-300 g) & 156.81 & 181.58 & 182.41 & - & $173.60 \mathrm{~A}$ \\
\hline Mean & $154.44 \mathrm{~b}$ & $176.96 \mathrm{a}$ & $178.53 \mathrm{a}$ & - & \\
\hline CV $(\%)_{\text {Shoot type }}$ & & & 1.36 & & \\
\hline \multirow[t]{2}{*}{$\mathrm{CV}(\%)_{\text {Induction age }}$} & & & 3.28 & & \\
\hline & \multicolumn{5}{|c|}{ Harvest duration (days) } \\
\hline Slip (100-200g) & 23.75 & 32.75 & 40.50 & 19.75 & 29.19A \\
\hline Sucker $(201-300 \mathrm{~g})$ & 31.25 & 27.75 & 47.50 & 21.50 & $32.00 \mathrm{~A}$ \\
\hline Mean & $27.5 b$ & $30.25 b$ & $44.00 \mathrm{a}$ & $20.62 b$ & \\
\hline CV $(\%)_{\text {Shoot type }}$ & & & 32.44 & & \\
\hline \multirow[t]{2}{*}{$\mathrm{CV}(\%)_{\text {Induction age }}$} & & & 29.70 & & \\
\hline & \multicolumn{5}{|c|}{ Thermal sum of floral induction to harvest onset (degree- days) } \\
\hline Slip (100-200 g) & $1,595.9$ & $1,410.9$ & $1,056.1$ & - & $1,354.3 \mathrm{~A}$ \\
\hline Sucker $(201-300 \mathrm{~g})$ & $1,608.4$ & $1,425.4$ & $1,187.7$ & - & $1,407.2 \mathrm{~A}$ \\
\hline Mean & $1,602.2 \mathrm{a}$ & $1,418.2 b$ & $1,121.9 \mathrm{c}$ & - & \\
\hline $\mathrm{CV}(\%)_{\text {Shoot type }}$ & & & 3.63 & & \\
\hline \multirow[t]{2}{*}{$\mathrm{CV}(\%)_{\text {Induction age }}$} & & & 5.34 & & \\
\hline & \multicolumn{5}{|c|}{ Thermal sum of planting to harvest onset (degree-days) } \\
\hline Slip (100-200 g) & $3,499.2$ & $4,034.3$ & $4,545.8$ & $5,007.2$ & $4,271.6 \mathrm{~B}$ \\
\hline Sucker $(201-300 \mathrm{~g})$ & $3,512.2$ & $4,050.4$ & $4,676.9$ & $5,006.8$ & $4,311.6 \mathrm{~A}$ \\
\hline Mean & $3,505.7 \mathrm{~d}$ & $4,042.3 \mathrm{c}$ & $4,611.4 b$ & $5,007.0 \mathrm{a}$ & \\
\hline $\mathrm{CV}(\%)_{\text {Shoot type }}$ & & & 0.76 & & \\
\hline $\mathrm{CV}(\%)_{\text {Induction age }}$ & & & 1.70 & & \\
\hline
\end{tabular}

${ }^{(1)}$ Means followed by equal letters, uppercase in the columns and lowercase in the lines, do not differ by Tukey's test, at $5 \%$ probability. ${ }^{(2)}$ - Not determined. 
the type of shoot (Table 2). The period from planting to the beginning of the harvest, which includes the vegetative and reproductive phases, was longer in naturally induced plants, and it decreased according to the age of artificial induction. The duration of this period was approximately $20,19,16$, and 13 months, respectively for naturally induced plants and at 12 , 10 , and 8 months. These differences for the period from planting to the beginning of the harvest are in agreement with studies conducted in other regions (Kist et al., 2011), showing the possibility of using ethephon for pineapple production scheduling also in the north of Espírito Santo state.

Liu et al. (2018) suggested that the induction with ethephon triggered the photoperiodic pathway for flower initiation, therefore, explaining the independent flowering of the inductive photoperiod. Ethephonmediated induction probably mimics the process of vernalization in the floral transition, increasing the expression, and promoting a positive regulation of the floral meristem identity genes involved in flower development (Liu \& Fan, 2016).

The following phase is the reproductive one and includes flowering and fruiting (Cunha, 2005). In our experiment, the duration of this phase was approximately five months for plants induced at 8 months (Table 2). The onset of flowering of naturally induced plants was not evaluated, but the reproductive period in naturally induced plants is believed to be approximately 6 months. The reduction in about one month in the reproductive period of plants induced at 8 months can be explained by the action of temperature (Figure 1). In most Brazilian producing regions, this period lasts for five to five and a half months, when fruit maturation occurs in the hottest period, and it lasts from five and a half to six months, when the maturation happens in the coldest season (Ganem, 2015).

The induction at 8 months was performed in December (Figure 3). According to Espinosa et al. (2017), 72 hours after the application of Ethrel, the differentiation of the apical meristem of the aerial part in flower buds is already observed. Therefore, the reproductive period occurred between December 2015 and May 2016 (Figure 3), when temperatures were higher (averages from 24.2 to $27.7^{\circ} \mathrm{C}$ ). Only in May, at ripening time of these fruit, the minimum average temperature was lower $\left(20.5^{\circ} \mathrm{C}\right)$. Zhang et al. (2011) observed that fruit development in the winter was 40 days longer than in the summer. However, although the environment was favorable for fruiting, plants induced at 8 months showed a lower vegetative development,
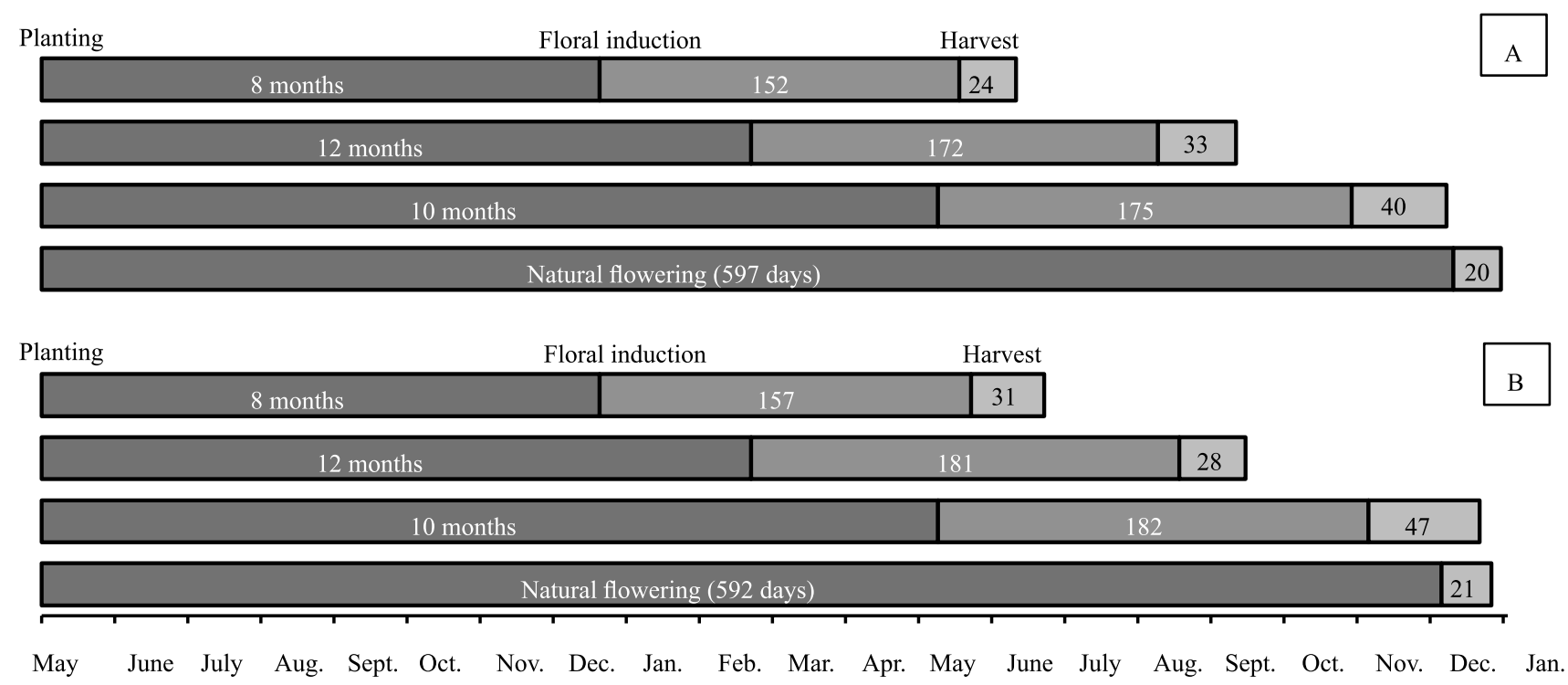

Figure 3. Cycle of 'Vitória' pineapple (Ananas comosus) with 100 to $200 \mathrm{~g}$ slip shoot (A), and 201 to $300 \mathrm{~g}$ sucker shoot (B) artificially induced, at 8, 10, 12 months after planting, and natural flowering. 
which resulted in reduced yield (Table 1) and fruit size (Figure 2).

Regarding plants induced at 12 months, the reproductive phase occurred from April to September 2015 (Figure 3), when the lowest temperatures were observed (Figure 1), which caused the increase of the harvesting period, in comparison with other treatments (Table 2). The increase of the harvesting period can be explained by the effect of temperature on the color of the peel, considering that the standardization of the harvest criterion is the apparent fruit ripeness.

When fruit development ends, the ripening period begins, with a change of the peel color from green to yellow and, after two weeks, it reaches the commercial standard (Zhang et al., 2016). Temperature has a great influence on the peel color. In the summer, the highest content of total chlorophyll and the lowest level of carotenoids are observed (Joomwong, 2006).

The influence of temperature on the development of pineapple plants can be quantified by the values of the thermal sum (Table 2). The thermal sum in the reproductive period increased sequentially at 8 , 10, and 12 months. Carvalho et al. (2005) also found that the later is the induction, the lower is the thermal sum value. Higher-thermal sum values suggest that more days are required to meet the thermal flowering requirements (Kist et al., 2011). This result can be explained by the lower vegetative development at the time of floral induction (Table 1) because, to be responsive to inductive factors, the plants need to reach a specific size (Cunha, 2005).

In the natural and artificial floral induction performed at 12, 10, and 8 months, the value of the thermal sum was sequentially higher, considering both the vegetative and reproductive developments (period from planting to harvest). As soon as they were subjected to the ethephon treatments, the plants started flowering, shortening the productive cycle proportionally to the induction period, showing the efficiency of the technique once more. Non-induced plants received the flowering stimuli only in July, when the low-night temperatures coincided with the shorter length of the day.

The flowering management made allowed of the production scheduling (Figure 3). Flower induction at 8 and 10 months made it possible to harvest between May and August, when the market prices are more favorable to the farmer, according to Ceasa-ES (2017).
The harvests referring to natural and 12-month floral induction occurred between October and December, when prices are lower due to the concentration of the crop (Ceasa-ES, 2017).

The total mass of artificially induced plant fruit was below the standards required for fresh consumption and export (Figure 2). According to Ceagesp (2003), pineapple fruit must have at least from 900 to 1,200 $\mathrm{g}$ for domestic fresh consumption, and 700 to 2,300 $\mathrm{g}$ for export. However, fruit with lower mass can be processed for juice or candy industries (Vilela et al., 2015).

\section{Conclusions}

1. Shoot types do not affect the performance of pineapple 'Vitória'.

2. The number of leaves is the vegetative variable that best expresses the ability of the pineapple plant to support productivity, at the time of floral induction, and it is directly proportional.

3. Early flower induction reduces productivity by reducing the fruit mass.

\section{Acknowledgments}

To Coordenação de Aperfeiçoamento de Pessoal de Nível Superior (Capes), for scholarship granting (Finance code 001) and to Fundação de Amparo à Pesquisa e Inovação do Espírito Santo (Fapes), for support with the experimental resources; and to Instituto Capixaba de Pesquisa, Assistência Técnica e Extensão Rural (Incaper), for permitting the use of the experimental areas and the plant and postharvest physiology laboratory.

\section{References}

ALVARES, C.A.; STAPE, J.L.; SENTELHAS, P.C.; GONÇALVES, J.L. de M.; SPAROVEK, G. Köppen's climate classification map for Brazil. Meteorologische Zeitschrift, v.22, p.711-728, 2013. DOI: https://doi.org/10.1127/09412948/2013/0507.

BARKER, D.L.; ARANTES, S.D.; SCHMILDT, E.R.; ARANTES, L. de O.; FONTES, P.S.F.; BUFFON, S.B. Postharvest quality of 'Vitória' pineapple as a function of the types of shoots and age of the plant for floral induction. Revista Brasileira de Fruticultura, v.40, e-297, 2018. DOI: https://doi. org/10.1590/0100-29452018297. 
BRASIL. Ministério da Agricultura, Pecuária e Abastecimento. Relação dos padrões oficiais estabelecidos pelo Ministério da Agricultura, Pecuária e Abastecimento para a classificação. Atualizado em 03.03.2017. Available at: <http://www. agricultura.gov.br/assuntos/inspecao/produtosvegetal/arquivos/ RELAODOSPRODUTOSPADRONIZADOS03032017.pdf $>$. Accessed on: Mar. 202017.

CARVALHO, S.L.C. de; NEVES, C.S.V.J.; BÜRKLE, R.; MARUR, C.J. Épocas de indução floral e soma térmica do período do florescimento à colheita de abacaxi 'Smooth cayenne'. Revista Brasileira de Fruticultura, v.27, p.430-433, 2005. DOI: https://doi.org/10.1590/S0100-29452005000300022.

CEAGESP. Centro de Qualidade em Horticultura. Programa Brasileiro para a Modernização da Horticultura: Normas de Classificação do Abacaxi. São Paulo, 2003. (CQH. Documentos, 24). Available at: $<$ http://www.hortibrasil.org.br/images/stories/ folders/abacaxi.pdf>. Accessed on: Apr. 252017.

CEASA-ES. Centrais de Abastecimento do Espírito Santo S.A. Calendário de comercialização dos principais produtos hortigranjeiros: baseado na Série histórica de 2010 a 2015. Available at: <https://ceasa.es.gov.br>. Accessed on: Apr. 12017.

CHENG, Y.; BARTHOLOMEW, D.; QIN, Y. Biology of the pineapple plant. In: MING, R. (Ed.). Genetics and genomics of pineapple. Cham: Springer, 2018. p.27-40. (Plant genetics and genomics: crops and models, 22). DOI: https://doi.org/10.1007/9783-030-00614-3.

CRUZ, C.D. GENES: a software package for analysis in experimental statistics and quantitative genetics. Acta Scientiarum. Agronomy, v.35, p.271-276, 2013. DOI: https://doi.org/10.4025/actasciagron.v35i3.21251.

CUNHA, G.A.P. da. Applied aspects of pineapple flowering. Bragantia, v.64, p.499-516, 2005. DOI: https://doi.org/10.1590/ S0006-87052005000400001.

EBEL, A.I.; GIMÉNEZ, L.I.; GONZÁLEZ, A.M.; LUACES, P.A. Evaluación morfoanatómica de hojas "D" de piña (Ananas comosus (L.) Merr. var. comosus) en respuesta a la implantación de dos sistemas de cultivo en Corrientes, Argentina. Acta Agronomica, v.65, p.390-397, 2016. DOI: https://doi.org/10.15446/ acag.v65n4.50560.

ESPINOSA, M.E.Á.; MOREIRA, R.O.; LIMA, A.A.; SÁGIO, S.A.; BARRETO, H.G.; LUIZ, S.L.P.; ABREU, C.E.A.; YANESPAZ, E.; RUÍZ, Y.C.; GONZÁLEZ-OLMEDO, J.L.; CHALFUNJÚNIOR, A. Early histological, hormonal, and molecular changes during pineapple (Ananas comosus (L.) Merrill) artificial flowering induction. Journal of Plant Physiology, v.209, p.11-19, 2017. DOI: https://doi.org/10.1016/j.jplph.2016.11.009.

FAO. Food and Agriculture Organization of the United Nations. Faostat: Crops Database. Available at: <http://faostat3.fao.org/ browse/Q/QC/E>. Accessed on: Apr. 272019.

FASSINOU HOTEGNI, V.N.; LOMMEN, W.J.; AGBOSSOU, E.K.; STRUIK, P.C. Influence of weight and type of planting material on fruit quality and its heterogeneity in pineapple [Ananas comosus (L.) Merrill]. Frontiers in Plant Science, v.5, art.798, 2015. DOI: https://doi.org/10.3389/fpls.2014.00798.
FRANCISCO, J.P.; DIOTTO, A.V.; FOLEGATTI, M.V.; SILVA, L.D.B. da; PIEDADE, S.M. de S. Estimativa da área foliar do abacaxizeiro cv. Vitória por meio de relações alométricas. Revista Brasileira de Fruticultura, v.36, p.285-293, 2014. DOI: https:// doi.org/10.1590/0100-2945-216/13.

GANEM, E.L. de. O. A cultura do abacaxizeiro. Vitória da Conquista: CETEP, 2015. Available at: $<$ http://www.ifcursos. com.br/sistema/admin/arquivos/09-10-16-abacaxizeiroeditadocultivo. pdf $>$. Accessed on: July 282019.

GUARÇONI M., A.; VENTURA, J.A. Adubação N-P-K e o desenvolvimento, produtividade e qualidade do abacaxi 'Gold' (MD-2). Revista Brasileira de Ciência do Solo, v.35, p.1367-1376, 2011. DOI: https://doi.org/10.1590/S0100-06832011000400031.

JOOMWONG, A. Impact of cropping season in Northern Thailand on the quality of Smooth Cayenne pineapple. II. Influence on physico-chemical attributes. International Journal of Agriculture \& Biology, v.8, p.330-336, 2006.

KIST, H.G.K.; RAMOS, J.D.; SANTOS, V.A. dos; RUFINI, J.C.M. Fenologia e escalonamento da produção do abacaxizeiro 'Smooth Cayenne' no Cerrado de Mato Grosso. Pesquisa Agropecuária Brasileira, v.46, p.992-997, 2011. DOI: https://doi.org/10.1590/ S0100-204X2011000900004.

KÜSTER, I.S.; ALEXANDRE, R.S.; ARANTES, S.D.; SCHMILDT, E.R.; ARANTES, L. de O.; KLEM, D.L.B. Phenotypic correlation between leaf characters and physical and chemical aspects of cv. Vitória pineapple fruit. Revista Brasileira de Fruticultura, v.40, e-964, 2018. DOI: https://doi. org/10.1590/0100-29452018964.

LIU, C.-H.; FAN, C. De novo transcriptome assembly of floral buds of pineapple and identification of differentially expressed genes in response to ethephon induction. Frontiers in Plant Science, v.7, art.203, 2016. DOI: https://doi.org/10.3389/fpls.2016.00203.

LIU, C.-H.; LIU, Y.; SHAO, X.-H.; LAI, D. Comparative analyses of the transcriptome and proteome of Comte de Paris and Smooth Cayenne to improve the understanding of ethephon-induced floral transition in pineapple. Cellular Physiology and Biochemistry, v.50, p.2139-2156, 2018. DOI: https://doi.org/10.1159/000495057.

MARQUES, L.S.; ANDREOTTI, M.; BUZETTI, S.; TEIXEIRA FILHO, M.C.M.; GARCIA, C.M. de P. Análise química da folha "D" de abacaxizeiro cv. Smooth Cayenne antes e após a indução floral em função de doses e parcelamentos de nitrogênio. Bioscience Journal, v.29, p.41-50, 2013.

MARUTHASALAM, S.; SHIU, L.Y.; LOGANATHAN, M.; LIEN, W.C.; LIU, Y.L.; SUN, C.M.; YU, C.W.; HUNG, S.H.; KO, Y.; LIN, C.H. Forced flowering of pineapple (Ananas comosus cv. Tainon 17) in response to cold stress, ethephon and calcium carbide with or without activated charcoal. Plant Growth Regulation, v.60, p.83-90, 2010. DOI: https://doi.org/10.1007/ s10725-009-9421-9.

PREZOTTI, L.C.; GOMES, J.A.; DADALTO, G.G.; OLIVEIRA, J.A. de. (Ed.). Manual de recomendação de calagem e adubação para o Estado do Espírito Santo: $5^{\text {a }}$ aproximação. Vitória: SEEA/INCAPER/CEDAGRO, 2007. 305p.

REINHARDT, D.H.R.C.; BARTHOLOMEW, D.P.; SOUZA, F.V.D.; CARVALHO, A.C.P.P. de; PÁDUA, T.R.P. de; 
JUNGHANS, D.T.; MATOS, A.P. de. Advances in pineapple plant propagation. Revista Brasileira de Fruticultura, v.40, e-302, 2018. DOI: https://doi.org/10.1590/0100-29452018302.

SAHOO, A.K.; KAR, I.; MOHANTY, A.; PANDA, R.; BHOYAR, R.K. Use of plant growth regulators and fertilizer for regulating the flowering and quality of pineapple fruit - A review. Integrated Journal of British, v.2, p.30-37, 2015.

VILELA, G.B.; PEGORARO, R.F.; MAIA, V.M. Predição de produção do abacaxizeiro 'Vitória' por meio de características fitotécnicas e nutricionais. Ciência Agronômica, v.46, p.724-732, 2015. DOI: https://doi.org/10.5935/1806-6690.20150059.

VILLA NOVA, N.A.; PEDRO JÚNIOR, M.J.; PEREIRA, A.R.; OMETTO, J.C. Estimativa de graus-dia acumulados acima de qualquer temperatura base, em função das temperaturas máxima e mínima. São Paulo: USP, 1972. 8p. (Caderno de Ciência da Terra, v.30).

ZHANG, H.N.; SUN, W.S.; SUN, G.M.; LIU, S.H.; LI, Y.H.; WU, Q.S.; WEI, Y.Z. Phenological growth stages of pineapple (Ananas comosus) according to the extended Biologische Bundesantalt, Bundessortenamt and Chemische Industrie scale. Annals of Applied Biology, v.169, p.311-318, 2016. DOI: https://doi.org/10.1111/aab.12292.

ZHANG, X.M.; DOU, M.A.; YAO, Y.L.; DU, L.Q.; LI, J.G.; SUN, G.M. Dynamic analysis of sugar metabolism in different harvest seasons of pineapple (Ananas comosus L. (Merr.)). African Journal of Biotechnology, v.10, p.2716-2723, 2011. DOI: https://doi.org/10.5897/AJB10.1284. 